\title{
Medisinstudenter i Trondheim tar vare på byens ry
}

\author{
Feiring en hel uke til ende kulminerte i et storslått jubileumsball da linjeforeningen MF Placebo fylte 40 år. \\ Frivilligheten står sterkt i Norges beste studentby.
}

I forbindelse med 40-årsmarkeringen for opprettelsen av medisinutdanningen ved Norges teknisk-naturvitenskapelige universitet (NTNU) i Trondheim i 2015, fulgte studentene opp med sin egen jubileumsfeiring (1). Norges teknisk-naturvitenskapelige universitet og byen Trondheim ønsker å skape Nordens beste universitet og studieby, og for å oppnå dette er byens studentfrivillighet svært viktig. Sammen med Studentersamfundet $\mathrm{i}$ Trondhjem er de ulike linjeforeningene med på å danne grunnmuren for denne frivilligheten.

For medisinstudentene er det Medisinerforeningen (MF) Placebo som sørger for at det ikke bare utdannes dyktige leger, men også at det sosiale er ivaretatt. I motsetning til de fleste andre linjeforeninger har MF Placebo ingen opptaksprøver. Alle medisinstudenter blir automatisk medlemmer gjennom obligatorisk deltagelse i fadderuken - en meget effektiv måte å rekruttere på. Det er heller ingen utmeldingsrett, og 40-åringen kan derfor skilte med et frafall på $0 \%$.

I revysangen $\mathrm{Nu}$ klinger igjennem den gamle stad (fra UKA 1929) oppfordres studentene til å sette sitt preg på byen: «La'kke byen få ro, men la den få merke den er en studenterby!» (2). Medisinstudentene bestemte seg for å ta ansvar for dette fra første stund og stiftet MF Placebo på det første allmøtet 15. januar 1976. Men antall studenter var lavt, og mange var allerede godt etablert da de ankom Trondheim for å gjøre ferdig klinisk arbeid (1). Det resulterte i lite engasjement for linjeforeningen, til tross for flere forsøk på resuscitering. Studentengasjementet har tatt seg betydelig opp de siste 20 årene, noe som kan leses av den digitale tidslinjen på nett (3).

\section{Feiring en hel uke}

Ved planleggingen av jubileet ble det tidlig enighet om at linjeforeningen fortjente en storslått feiring - en hel uke i februar til ende. Det innebar rebusløp i Bymarka, swingkurs, jubileumskonsert med medisinerkorene Bilyd og Foetus Ex Ore, engasjerende foredrag om kjønnslemlestelse med Safia Abdi Haase og en quizkveld så het at man kunne skrive svaret i duggen på vinduene (4). Flere av de tilreisende fikk også med seg revykavalkaden i Storsalen på Studentersamfundet, selve symbolet på studentbyen Trondheim. Flerårig regissør for MedHum-revyen, Andreas Aass Engstrøm, samlet skuespillere og viste frem det beste revystoffet produsert av medisinmiljøet i Trondheim gjennom tidene. Og dét for en fullsatt sal og et elektrisk ladet publikum, som nærmest løftet taket av Storsalen denne kvelden.

\section{Ball}

Feiringen ble avsluttet med hovedattraksjonen - Jubileumsballet. Dette ble arrangert på Scandic Lerkendal med 820 påmeldte gjes-

\section{«En quizkveld så het \\ at man kunne skrive svaret i duggen på vinduene»}

ter, med både tidligere og nåværende studenter. Siden 1975 har ca. 3100 personer påbegynt medisinstudiet ved Norges teknisk-naturvitenskapelige universitet, og arrangøren var derfor svært fornøyd med å ha fått med nesten en tredel av dem.

En spørreundersøkelse var utsendt på forhånd og ga 366 svar som var likt fordelt mellom leger og studenter. Det er all rimelig grunn til å tro at det forelå seleksjonsbias, og det var heller ikke sikkert om alle som hadde svart, var til stede under festen. Uansett viste en multippel lineær regresjonsmodell et gjennomsnitt på 3,9 alkoholenheter per uke korrigert for kjønn og studentstatus. Forfatterne ser med bekymring på at både kvinner og leger drikker mer enn forventet, særlig når referansegruppen er mannlige studenter.

Jubileumsballet ble en forrykende feiring, fylt med tradisjoner, taler, latter og ikke minst korpsmusikk fra medisinerorkesteret MS Orch. Sammen med Bilyd og Foetus ex Ore fremførte de den fremragende Jubileumshymnen, skrevet og arrangert $\mathrm{i}$ anledning 40-årsmarkeringen. Ei heller glemmes den nydelige fremførelsen av Kjcerlighetsvise til byen fra UKA-revyen 2004, eller det øyeblikk da $\mathrm{Nu}$ klinger igjennem den gamle stad samlet 820 gallakledde gjester i en fan- tastisk, rungende allsang. Rektor Gunnar Bovim (1960-) formidlet sine gratulasjoner på storskjermen, og blant æresgjestene var selvsagt medisinstudiets «far» i Trondheim, Jon Lamvik (1929-), sentralt plassert. Kveldens konferansierer var to av studiets mest populære forelesere, Brita Pukstad (1969-) og Jostein Halgunset (1951-). Sistnevnte stakk ( $\sin$ vane tro) av med en av kveldens gjeveste titler, Arets foreleser.

Mot kveldens ende var dansegulvet fylt med svingende jubilanter, for det er ingen hemmelighet at swingdans hører enhver medisinerfest til. Også medisinerbandet Tacky Cardia satte sitt preg på kvelden, og det hele toppet seg da bassisten stjal showet med sin trønderinspirerte fremføring av DDEs Her blir det liv. Det mest gledelige var å se at MF Placebos jubileumsfeiring hadde gjenforent kullinger fra de glade 70-, 80-, 90- og 00-årene, de fleste fra kull 2014 og de eldste fra kull 76B. Alle deltagerne gikk hjem med selve symbolet på fellesskapet, «jubileumsdaljen» (fig 1), hengende på brystet. Jubileumskomiteen velger å ta det som et tegn på at de lykkes i å forene gamle og nye studenter i felles tilhørighet.

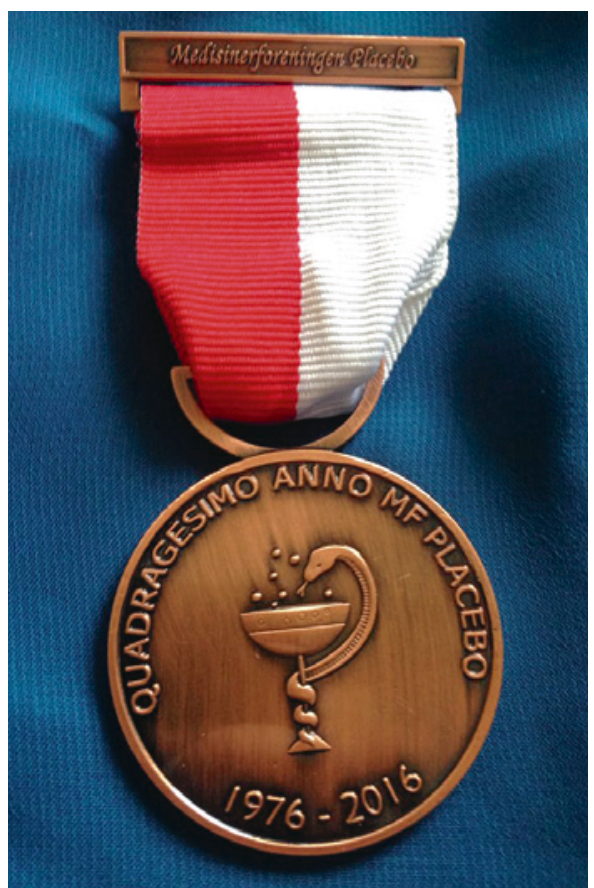

Figur 1 Jubileumsmedaljen til MF Placebo, med logo inspirert av Asklepios' stav, tegnet av Joanna Sulkowska. . Foto: Heidi Heitmann Viken 


\section{legelivet}

Vi takker Geir Wenberg Jacobsen for råd og veiledning under forberedelse av manuskriptet.

\section{Inga Skogvold Rygg}

Heidi Heitmann Viken

Trond Nordseth

trond.nordseth@ntnu.no

Inga Skogvold Rygg (f. 1991) er medisinstudent ved Norges teknisk-naturvitenskapelige universitet og lokal representant for Norsk medisinstudentforening.

Forfatter har fylt ut ICMJE-skjemaet og oppgir ingen interessekonflikter.

Heidi Heitmann Viken (f. 1989) er medisinstudent ved Norges teknisk-naturvitenskapelige universitet og tidligere styrerepresentant i MF Placebo.

Forfatter har fylt ut ICMJE-skjemaet og oppgir ingen interessekonflikter.

Trond Nordseth (f. 1977) er tidligere MF Placebo-sjef, overlege ved Klinikk for anestesi og intensivmedisin, St. Olavs hospital, og førsteamanuensis ved Det medisinske fakultet, Norges teknisk-naturvitenskapelige universitet. Forfatter har fylt ut ICMJE-skjemaet og oppgir ingen interessekonflikter.

\section{Litteratur}

1. Jacobsen GW, Hansen AS. Medisinstudiet

i Trondheim 1975-2015. Tidsskr Nor Legeforen

2015; 135: 2090-1.

2. Studentersang. Fra Wikipedia.

https://no.wikipedia.org/wiki/Studentersang

(5.7.2016).

3. StudMed-historie Trondheim, tidslinje.

http://bit.ly/29tSig6. (5.7.2016).

4. Nordseth T. For lege og student - Mannskoret Foetus ex Ore 20 àr. Tidsskr Nor Legeforen 2013; 133: 2540

Mottatt 5.7. 2016 og godkjent 7.7. 2016. Redaktør: Kaveh Rashidi.

Publisert først på nett. 